\title{
EU NÃO TENHO PARADEIRO CERTO! Couro, boi e mióla no bumba meu boi maranhense ${ }^{1}$
}

\author{
I HAVE NO RIGHT WHEREABOUTS! \\ Leather, bull and miola in the bumba-meu-boi maranhense
}

Lady Selma Ferreira Albernaz

\begin{abstract}
Resumo
Muitos são os escritos sobre bumba-meu-boi do Maranhão, entretanto, poucos são aqueles que tratam da relação entre humanos e não humanos nesta brincadeira. Neste trabalho, pretendo analisar a ênfase dada ao couro do boi durante os festejos, que pode obscurecer o processo de sua formação, bem como as ações que dão vida ao boi na relação com o miolo (pessoa que movimenta o boi-artefato), posição ocupada majoritariamente por homens. A ênfase sobre a estética do couro será analisada simbolicamente. Já no que se refere à junção boi e miolo, tentarei uma análise de como o animal ganha vida nesta brincadeira, inspirada na definição de "coisa" de Tim Ingold (2012). Tenho por base empírica a entrevista, realizada em 2009, com Mauricéia, única mulher nesta função de miolo, bem como as observações do movimento e dança do boi com os brincantes, nos trabalhos de campo realizados em diferentes momentos durante o São João maranhense.
\end{abstract}

Palavras-chave: Festas e rituais. Coisa. Miolo do boi. Gênero.

\begin{abstract}
Many are the writings on bumba-meu-boi of Maranhão, however, few are those that consider of the relationship between humans and non-humans in this play. In this work I intend to analyze the emphasis given to the bull's hide during the festivities, which may obscure the process of its formation, as well as the actions that give life to the ox in relation to the kernel (person that moves the bull-artefact) mostly by men. The emphasis on leather aesthetics will be analyzed symbolically. As far as the bull and kernel joint is concerned I will try to analyze how the animal comes to life in this game, inspired by Tim Ingold's definition of "thing" (2012). I have the empirical basis for the interview with Mauriceia, the only woman in this kernel role, when the conversation was held in 2009, as well as the observations of the bull movement and dance with the players, in the field work carried out at different times during São João maranhense.
\end{abstract}

Keywords: Festivals and rituals. Thing. Kernel of the bull. Gender.

\footnotetext{
1 Este artigo baseia-se em resultados da investigação: Concepções sobre corporeidade e fertilidade femininas entre brincantes de bumba meu boi maranhense e de maracatu pernambucano (CNPq - Processo no 402901 / 2008-8; Edital no 57/2008). Participaram as bolsistas de iniciação científica: Teresa Maria Barbosa de Oliveira e Maíra Souza e Silva Acioli (2006/2007), Bárbara Lopes Lima (2007/2008), Patrícia Geórgia Barreto de Lima (2008/2010), Ighara de Oliveira Neves (2009/2010), quando foram estudantes de graduação em Ciências Sociais na UFPE; e, Jailma Maria Oliveira (2009/2010), mestranda do PPGA-UFPE. Agradeço a colaboração de toda a equipe. Agradeço a Luciana Chianca por ter propiciado o encontro com Ulisses Rafael e Luciana Carvalho, em abril/2018 em João Pessoa. Foi revigorante e estimulou a escrita deste trabalho. Dedico este artigo à memória de minha mãe, Djanira Ferreira Leite, e ao meu filho, Pedro Magalhães, pelos laços de afeto estreitados nos últimos dois anos.

* Professora Associada 3, Departamento de Antropologia e Museologia, Universidade Federal de Pernambuco. Atua no Programa de Pós-Graduação em Antropologia (UFPE). E-mail: selma.albernaz@gmail.com
} 
Garota vem ver

União da Baixada chegou

No couro tá estampado

A seleção de jogador

Do outro lado é pai e filha

Que o Brasil consagrou

O bordado tá bem feito

Que Dona Tânia bordou

Bumba-meu-boi União da Baixada

São Luís/MA

\section{Guarnic $\hat{e}^{3}$}

Muitos são os escritos sobre bumba-meu-boi ${ }^{4}$ do Maranhão, entretanto, poucos são aqueles que tratam da relação entre humanos e não humanos nesta brincadeira ${ }^{5}$. Neste trabalho, pretendo analisar a ênfase dada ao couro do boi durante os festejos, que pode obscurecer o processo de sua formação, bem como as ações que dão vida ao boi na relação com o/a miolo/ mióla (pessoa que movimenta o boi artefato), posição ocupada majoritariamente por homens. A ênfase sobre a estética do couro será analisada simbolicamente. Já no que se refere à junção boi e miolo tentarei uma análise de como o animal ganha vida nesta brincadeira, inspirada na definição de "coisa" de Tim Ingold (2012):

Para criar algo, refletiu Aristóteles, deve-se juntar forma (morphé) e matéria (hyle). (...) A forma passou a ser vista como imposta por um agente com um determinado fim ou objetivo em mente sobre uma matéria passiva e inerte. (...) Meu objetivo (...) é derrubar o próprio modelo (...) [e dar] primazia aos processos de formação ao invés do produto final, e aos fluxos e transformações dos materiais ao invés dos estados da matéria. (INGOLD, 2012, p. 26).

Tenho por base empírica a entrevista com Mauricéia, na época em que conversamos, em 2009, ela era a única mulher nesta função de miolo - sendo chamada por seus colegas homens de mióla. Utilizo ainda as observações do movimento e dança do boi com os brincantes, durante os trabalhos de campo realizados em diferentes períodos das festas do São João maranhense. Esses dados são completados pela descrição da confecção do boi artefato, que não observei pessoalmente, contida na publicação: “Complexo Cultural do Bumba-meu-boi do Maranhão.

\section{2 (IPHAN, 2011, p. 182).}

3 Denominação da toada de abertura da brincadeira de boi no Maranhão.

4 A grafia do termo "bumba-meu-boi" é muito variada. Com exceção de citações e títulos de obras, adoto a forma utilizada no Dossiê de Registro do Bem pelo Iphan.

5 Entre os estudos de cultura popular, essa relação quase não é investigada. Localizei apenas o trabalho de Viviane Lima (2010), que faz uma análise simbólica dessa interface no bumba-meu-boi. 
Dossiê do registro como Patrimônio Cultural do Brasil” do Instituto do Patrimônio Histórico e Artístico Nacional (IPHAN, 2011). Também lanço mão do trabalho de Luciana Carvalho (2011), especialmente no que se refere à descrição de como o boi artefato é confeccionado.

O bumba-meu-boi é um folguedo/brincadeira popular brasileiro apresentado, geralmente, no período de Natal e Carnaval, em quase todas as regiões do país. Os maranhenses, somando-se aos estados do Norte, realizam o bumba-meu-boi em homenagem a São João, época do verão e das colheitas agrícolas ${ }^{6}$.

No Maranhão, o bumba-meu-boi compõe-se de auto e dança. Os personagens do auto, encenado ou aludido nas toadas, são: o "amo", dono do boi e da brincadeira; o animal boi; o casal pai Francisco e Catirina; e os vaqueiros. Formam um corpo de baile: índias, índios, caboclos de pena, rajados, dentre outros, que ocasionalmente podem atuar como personagem. O tema do auto é o roubo do boi pelo pai Francisco, seguido da morte, captura e ressurreição do animal7. Nesse estado, a manifestação é percebida como tradicional, pela sua permanência ao longo do tempo e pela manutenção de conteúdos simbólicos nesse processo de reprodução, permeado de disputas e negociações de significados.

Em trabalho de 2004, procurei demonstrar como o bumba-meu-boi constituiu-se em símbolo central numa configuração simbólica que afirma a identidade da região frente à nação. Nele, também destaquei a atenção que o couro do boi - sua cobertura de tecido - ganha nas apresentações por onde a brincadeira transita (ALBERNAZ, 2004, 2013). Entretanto, não tratei da relação entre boi e miolo, e nem de uma questão importante: como aquele artefato ganha vida, a ponto de o boi da brincadeira e o boi, animal vivo, tornarem-se indistintos um do outro, no grande ritual que é a festa do boi maranhense.

Feita esta rápida introdução, na continuidade, para dar conta de como o boi torna-se animado, iniciarei com a descrição do simbolismo e significados do couro relacionados com a afirmação de identidade ${ }^{8}$. Em seguida, descreverei a feitura do boi, sua formação e, finalmente, as impressões de Mauricéia, como miola de um boi maranhense. Nesta parte, as questões de gênero também afloram, especialmente por meio da noção de força, que na teoria de Ingold (2012) é um dos elementos importantes para compreender como as coisas estão no mundo em fluxo e em processo, assim como a vida: “...em um mundo onde há vida, a relação essencial se dá não entre matéria e forma, substância e atributos, mas entre materiais e forças”. (INGOLD, 2012 , p. 26). Encerro o texto com uma reflexão sobre possíveis ganhos analíticos resultantes de revisitar dados etnográficos com este enfoque teórico sobre a vida material.

6 O bumba-meu-boi maranhense é classificado em sotaques. Os principais são: zabumba ou Guimarães, ilha ou matraca, baixada ou pindaré, orquestra, e Cururupu ou de costa de mão. Para mais informações sobre esse sistema de classificação, ver: Albernaz (2004; 2013)

e Carvalho (2011).

7 Para mais detalhes sobre o auto, ver: Carvalho (2011).

8 Sintetizei a noção de identidade a partir de vários autores, exposta em detalhes em Albernaz (2004). 


\section{O couro do boi nas festas do bumba-meu-boi em São Luís-MA}

A festa do boi no Maranhão está dividida em quatro fases: ensaios, batizado, apresentações e morte do boi. Os ensaios preparam a festa e o grupo9. O batizado é um ritual para apresentar o couro e proteger o grupo para dançar fora do terreiro - como geralmente é chamado o pátio da sede. A fase das apresentações se caracteriza pela realização de encenações pagas ou para retribuir aos colaboradores do grupo que contribuíram na sua organização prévia. Por fim, o ritual da morte, que encerra o ciclo da festa ${ }^{10}$.

O batizado deve ser no dia 23 de junho, véspera de São João ${ }^{11}$. Nesse momento, todo o folguedo está simbolizado na figura mesma do boi, o qual é colocado em cima de uma mesa, com o couro coberto pela barra/saia - aumentando o mistério em torno do motivo do bordado. Por trás fica um pequeno altar, ornamentado com flores e velas, com a imagem de São João em destaque. O boi é que será batizado, apenas ele, imóvel sobre a mesa, ladeado pelos padrinhos, o amo e os oficiantes da cerimônia, seguidos pelas autoridades políticas - no geral do poder legislativo e executivo. Em círculos sucessivos, vão se dispondo todos que vieram ver a sagração do boi, inclusive os brincantes, que não ocupam lugares específicos. Essa consagração é simultaneamente um ritual de purificação e de proteção para a saída do boi para os espaços das apresentações, que ocorrerão até o ritual da morte, que encerra o ciclo anual da brincadeira. Neste conjunto de atividades, o ponto alto é o momento de revelar o novo couro do boi para os brincantes e para a assistência. Destaca-se a apreciação do bordado, tanto as imagens, quanto a perfeição das figuras, e a qualidade dos materiais.

\footnotetext{
Em geral, o ritual do batismo é realizado por rezadeiras que cantam ladainhas em latim conservado e apropriado pelo povo com uma linguagem própria. A reza é acompanhada em coro pelos devotos presentes, já familiarizados com o ritual. Após a reza, a madrinha, seguida pelo padrinho, orientados pelo dono do Boi, que conduz a cerimônia, seguram no chifre do boi e abençoam o novilho com um galho de vassourinha, com o qual fazem o sinal da cruz, derramando a água benta sobre a cabeça e corpo do "afilhado" e proferindo o seguinte verso, seguido do sinal da cruz:

Eu te batizo (nome do boi batizado)

Com toda a tua formosura

Só não te dou os santos óleos

Porque não és criatura.

Em nome do Pai e do Filho e do Espírito Santo.

Amém.
}

9 Para mais detalhes sobre a festa, ver Albernaz (2004) e Carvalho (2011).

10 Para análise que se segue, baseie-me nos trabalhos de Edward Thompson (1981; 1998), especialmente a noção de experiência e, sobre ritual, guiei-me por Mariza Peirano (2002).

11 Informaram-me sobre mudanças na data do batismo, relacionadas a processos de continuidade do boi. Antecipá-lo é uma estratégia válida, pois realizá-lo após 23/06, implica perda do sentido de proteção para o grupo. 
No ritual de batismo, outras orações são rezadas e entoados cânticos de cerimônias católicas como: Pai Nosso, Ave Maria, Santa Maria, Salve Rainha, Credo, Hino e Bendito de São João. Freqüentemente, logo após a benção, são dados os “vivas” para Deus, Santo Antônio, São João e São Pedro. Toadas que tratam do ritual que findou são tiradas pelos amos proclamando que o Boi já foi batizado ou oferecendo o Boi ao santo padroeiro... (IPHAN, 2011, p. 118-119).

O apadrinhamento sintetiza uma gama de relações as quais dão sustentação ao grupo que organiza a brincadeira. Ele expressa as hierarquias, pois confere legitimidade a quem ocupa posições elevadas no grupo ou a quem irá ocupá-las. O ritual do batismo também condensa e apresenta para o grupo suas relações com a cidade de São Luís. Essas relações possibilitam compreender o prestígio e o significado da brincadeira para a cidade.

Por sua vez, algumas pessoas, que vêm de fora para assistir ao ritual, podem estar buscando reconhecimento na cidade de São Luís e, por conta disso, procuram ficar em lugares de destaque. Ou seja, ser "bem aceito" no grupo de boi pode significar maior prestígio por estar mais próximo de um símbolo que expressa, mais do que outros, o que é ser maranhense. E a aceitação do grupo que faz o boi, para aqueles que vêm de fora, parece ser maior quando é demonstrada no momento do batismo, posto que esse ritual demarca temporalidade - a partir dele o boi pode circular por toda a cidade - e apresenta o couro do boi para todos os participantes, reafirmando e trazendo novos símbolos e significados para o Maranhão.

Portanto, no batismo, a figura do boi torna-se fundamental e sua simbologia encontrase condensada nos bordados do couro, que recebe um reforço significativo com as novas indumentárias usadas pelo conjunto dos brincantes, especialmente o personagem do amo ${ }^{12}$. O que se vê retratado no couro do boi são: bandeiras, brasões, monumentos, políticos (os anti-heróis?), santos e divindades, entes da natureza, raças fundadoras da nação, lendas que se mesclam com o sentido local de história e o próprio boi - o símbolo de maior significado em que tudo se condensa. Não posso deixar de citar um romance, enquanto metáfora, que me parece dizer melhor que tipo experiência é mediada pelos bordados do seu couro:

A grande vantagem dos Zodíacos, Cartas de Baralhos, bandeiras, Brasões, (...) era que, com eles, eu enchia o Buraco cego e vazio do Mundo e o Deserto-assírio da minha alma. Sentindo meu sangue pulsar com violência, não havia mais como duvidar de mim. Meu sangue me garantia a existência do meu corpo, e o corpo, a de minha Alma $^{13}$. (SUASSUNA, 1970, p. 436).

12 Regina Prado (1977, p. 172) considera que o boi é um símbolo condensado e afirma que ele impregna "o bumba de uma polivalência de significados que nos alertam sobre os vários ângulos através dos quais este ritual pode ser analisado: como um conflito econômico e político, como um rito messiânico, como um lugar de brincadeira e um contexto religioso para o cumprimento de promessas".

13 Ariano Suassuna, Romance d'A Pedra do Reino (1970, p. 436). 
Em todos os grupos, independente do sotaque, o grande destaque do folguedo é o boi, personagem a partir do qual toda a trama se desenvolve. Por meio dele, e por ele, as relações sociais entre ricos e pobres, proprietários e empregados, entre negros, brancos e índios são encenadas - e a intensidade ritual exprime a estrutura social que caracteriza São Luís e o estado no seu conjunto. Da mesma forma, é por meio do boi que há uma comunicação entre o terreno e o celeste, pois ele é uma oferenda a São João. O boi celebra os santos de junho, cujas datas comemorativas coincidem com o verão maranhense e também com o período das colheitas do ano. Como uma festa de origem camponesa, nela se agradece os frutos da terra (PRADO, 1977). É uma festa na qual são condensadas as relações sociais, as relações entre homem e natureza e onde as relações entre os humanos e o sagrado podem expressar, tanto o social, como o ambiente onde se situam.

Encerrado o batismo, o grupo realiza sua primeira apresentação que pode ser no seu terreiro ou fora dele. A partir daí a festa será intensa, passa a se chamar "fase de apresentações", período no qual o boi circula por diferentes arraiais, distribuídos em vários pontos da cidade - da periferia ao centro, em locais públicos ou privados (em residências particulares, porém ocupando todo o espaço da rua). Nesta fase, as apresentações são mais frequentes entre os dias 23 a 30 de junho, vão se tornando mais raras e, finalmente, devem se encerrar com o ritual da morte do boi, que ocorre no máximo até novembro. Na passagem do dia 28 para o 29, realiza-se a festa na igreja de São Pedro, incluindo procissão marítima e terrestre. No dia 30 é a festa de São Marçal, ou Festa do João Paulo, uma grande apoteose do ciclo do boi, que remete à história de resistência do bumba-meu-boi às perseguições da elite local (ALBERNAZ, 2004).

Vale notar que, durante as apresentações, o couro mantém sua importância e atrai a atenção da assistência. Somam-se a ele as toadas que mencionam, para elogiar ou ofender (os rivais), os motivos bordados no couro do boi. Nestas disputas, o amo parece se destacar, deslocando os significados condensados no couro do boi, para sua pessoa e posição que ocupa, posto que ele expressa, em versos de toadas, o que o couro traz figurativamente. Os símbolos bordados no couro e os versos das toadas reforçam-se mutuamente. Por exemplo, em 2002, o couro do boi da Maioba fazia referência à copa do mundo, e a toada Eu vi o meu Brasil jogar ${ }^{14}$ afirmava: "Eu vi o meu Brasil jogar no Castelão ${ }^{15}$ para se classificar (...) provou para o mundo inteiro/ Que o pé quente é o Maranhão." Os movimentos de dança do boi, com os personagens e com os brincantes do corpo de baile, permitem interações que dão relevo à forma boi e seus materiais e, como uma onda de ressonância, também integra a assistência nesta apreciação.

Os símbolos bordados no couro do boi são os meios para a assistência apreciá-lo e para os realizadores dos folguedos falarem da sua força, ou da sua fortaleza, como eles normalmente dizem. Na festa do João Paulo, o couro do boi pode ser apreciado bem de perto, o boi passa rente aos olhos de quem dança ou está nas calçadas. A beleza estética dos bordados parece se unir

14 Toada $\mathrm{n}^{\circ} 9$ do Cd da Maioba de 2002.

15 Estádio de futebol de São Luís, onde a seleção brasileira se classificou para a Copa de 2002. 
a estes sentidos, dando-lhes mais relevância. A arte contida no bordado, o tempo necessário para sua formação, o trabalho empregado, tudo reunido, parecem querer dizer que a própria identidade está ali contida no couro de veludo do boi, que encena as relações da sociedade que ele, em si, é convidado a representar.

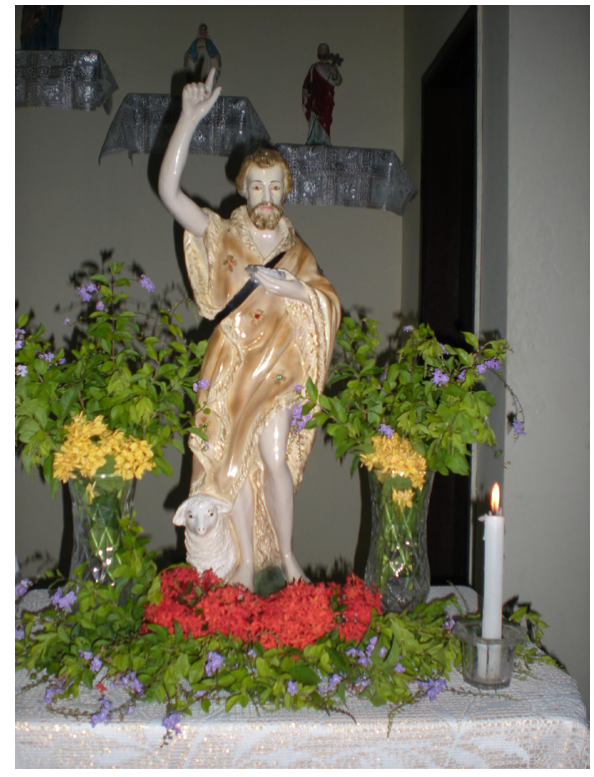

Imagem 1 - Altar de São João

(Acervo da pesquisa - 2009)

\title{
Formas e materiais na confecção do boi ${ }^{16}$
}

Numa das passagens do Dossiê do Registro do Bumba-meu-boi como patrimônio imaterial pelo Instituto do Patrimônio Histórico e Artístico Nacional, o boi é assim descrito:

\begin{abstract}
Para se apresentar em público, o boi é luxuosamente preparado. Se nas demais manifestações da brincadeira do boi no Brasil o boi-boneco se apresenta de forma simples, coberto de pano pintado ou estampado, no Maranhão é coberto de veludo bordado com dedicação - o couro do boi. Com miçangas, canutilhos e lantejoulas, o couro apresenta e representa o universo simbólico do Bumba. Lindos desenhos multicoloridos, de uma riqueza que só pode ser mensurada pela devoção ao santo protetor da brincadeira, retratam temas diversos como a religiosidade católica e de matriz africana dos maranhenses e homenagens a personalidades da vida política e cultural locais, dentre outros. (IPHAN, 2011, p. 28).
\end{abstract}

Essa citação reitera as interpretações feitas por mim no item precedente, mas, dessa vez, a escrita e sua interpretação tomará outra direção. Repito aqui parte da citação de Ingold que fiz no início: "Meu objetivo (...) é [dar] primazia aos processos de formação ao invés do produto

16 Conforme anunciei na introdução, nesta parte lançarei mão - algumas vezes mais longamente - dos dados referentes à confecção do boi artefato contidos nos trabalhos de Carvalho (2011) e do Instituto do Patrimônio Histórico e Artístico Nacional (2011). 
final, e aos fluxos e transformações dos materiais ao invés dos estados da matéria" (INGOLD, 2012, p. 26); porque essa proposta analítica guiará a descrição de como se forma um boi.

O texto de Ingold, que tomo por base, tem intenções mais amplas e generalizantes sobre os modos de pensar, sentir, viver no mundo, dentro dele e tendo suas superfícies vazadas - tanto os corpos humanos, como os materiais e as coisas, em movimento e em transformação. Como ele sintetiza, num ambiente sem objetos (ASO), porém preenchido de coisas. Ingold (2012, p. 29) faz a seguinte distinção entre objetos e coisas:

\begin{abstract}
Essas considerações me levaram a concluir que a árvore não é um objeto, mas um certo agregado de fios vitais. É isso que entendo por coisa. (...) O objeto coloca-se diante de nós como um fato consumado, oferecendo para nossa inspeção suas superfícies externas e congeladas. (...) A coisa, por sua vez, é um "acontecer", ou melhor, um lugar onde vários aconteceres se entrelaçam. Observar uma coisa não é ser trancado do lado de fora, mas ser convidado para a reunião. (...) Há decerto um precedente dessa visão da coisa como uma reunião no significado antigo da palavra: um lugar onde as pessoas se reúnem para resolver suas questões. (...) Assim concebida, a coisa tem o caráter não de uma entidade fechada para o exterior, que se situa no e contra o mundo, mas de um nó cujos fios constituintes, longe de estarem nele contidos, deixam rastros e são capturados por outros fios noutros nós. Numa palavra, as coisas vazam, sempre transbordando das superfícies que se formam temporariamente em torno delas.
\end{abstract}

Com esta sugestão analítica em mente, passo a descrever como o boi se forma, até ser apresentado nas festas juninas maranhenses.

Segundo Luciana Carvalho (2011, p. 256 e seg.), a confecção do boi inicia-se na mata - na vizinhança da capital ou mais no interior do estado. Da mata são cortadas e retiradas fibras e madeiras de diferentes tipos de acordo com seu uso para montar o boi. O trabalho de coleta deste material é feito por lavradores - em troca de transporte para brincar o São João na capital. As fibras e madeiras devem secar e receber tratamento apropriado para dar forma ao boi. Na sequência, esses materiais serão usados para montar a carcaça, armação ou capoeira ${ }^{17}$. Cada parte dela leva um tipo de madeira ou fibra vegetal: com a jeniparana, firme e flexível, modelam-se os arcos centrais da carcaça; com o buriti, fibra leve, faz-se o preenchimento; com a paparaúba, esculpe-se a cabeça. Somam-se às madeiras os chifres feitos a partir dos cornos de animais abatidos, que são tratados e polidos por um magarefe - profissional que faz abate de animais para consumo humano. No Dossiê do Iphan (2011, p. 186), há ainda outras informações: "A carcaça, capoeira ou cangalha é a armação do boi/boneco do Bumba-meu-boi do Maranhão. É uma estrutura feita de palha e madeiras leves, como o buriti, a jeniparana e a paparaúba. Fios, talos de buriti, metal e varas também são usados na confecção da carcaça, que se compõe de corpo, cabeça, chifres e rabo."

17 Capoeira é uma das terminologias para armação de madeira que conformam o boi. 


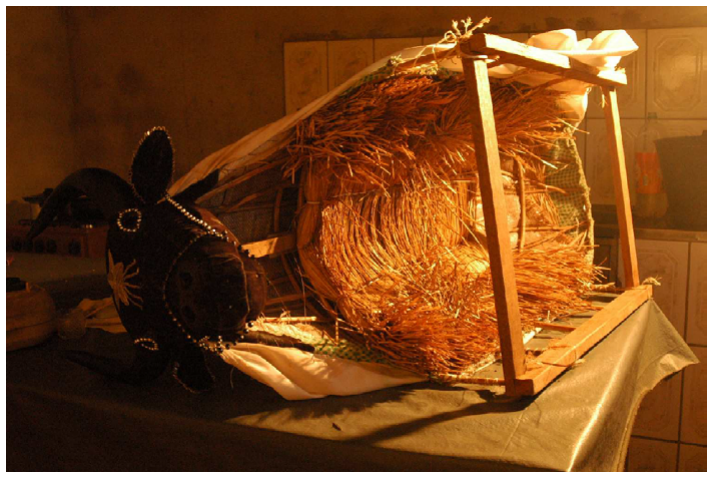

Imagem 2 - Carcaça (IPHAN, 2011, p. 186)

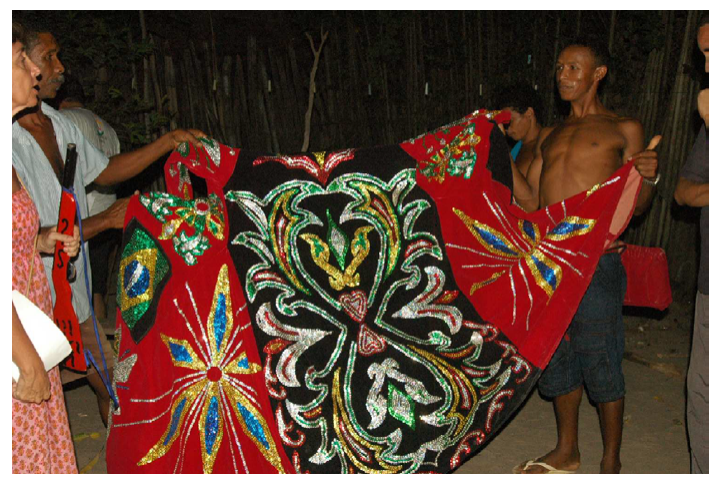

Imagem 3 - Couro finalizado (IPHAN, 2011, p. 185)

É possível perceber um desenrolar de acontecimentos envolvendo pessoas e materiais para que o boi seja formado. Na concepção de Ingold (2012), a ideia de uma finalidade prévia não é o que mais importa, mas antes o percurso de linhas que se encontram num ambiente em que se habita. Percebe-se que a ideia de habilidade, também empregada por este autor, ganha um realce nesse processo de formação do boi. Aqueles com maior contato com o ambiente natural de árvores e plantas, os lavradores, são os escolhidos para extrair as diferentes fibras vegetais que formam a armação do boi. Já os chifres são solicitados ao magarefe, um profissional que lida com a morte e sabe como manter e conservar partes de corpos de animais abatidos. Esse entretecer de relações é conduzido pelo dono do boi ou a pessoa responsável para esta tarefa.

Discordando de Ingold (2012), que apresenta as coisas como emaranhados de linhas, considero que as relações entre os humanos têm aspecto mais estruturado, por isso as posições e ofícios importam para que se tenha acesso ao conhecimento e ao desenvolver de habilidades para a formação das coisas, inclusive para que o seu devir possa ser pensado de maneira mais apropriada, posto que o mundo em que vivemos apresenta desigualdades econômicas, sociais e políticas que impedem o devir das coisas para certos sujeitos. Assim, o dono do boi ou responsável pela tarefa pode impedir ou direcionar o processo da formação do boi. Mais adiante retomo este debate. 
Passemos ao couro, que segundo o Iphan, é feito pelo processo a seguir:

\begin{abstract}
O couro que cobre a armação é feito comumente com veludo, em geral preto, bordado com miçangas, canutilhos, lantejoulas e paetês. (...) A cabeça é esculpida em um bloco igualmente leve, porém maciço, recebendo como acabamento um par de chifres naturais polidos e enfeitados com ponteira de metal brilhoso ou fitas de cetim coloridas. No lugar dos olhos, a semente silvestre "olho de boi" ou bolas de gude. Na testa traz uma determinada imagem que pode ser de uma estrela, pomba do divino, flor e São João, entre outras. Na base da armação é costurada a barra, uma espécie de saia comprida de tecido vistoso que esconde as pernas do miolo. (...) As técnicas de confecção são bastante variadas. Não há manuais ou modelos rígidos, embora muitos conhecimentos e padrões sejam transmitidos e preservados. (...) há outras técnicas de decalcar o desenho e fixá-lo no veludo. (...) depois de pronto o bordado, o couro é retirado do bastidor e fixado na armação da carcaça e na cabeça do boi. Para a fixação, geralmente é utilizada cola fórmica e, em seguida, o bordador alinhava o couro nas peças. (...) Acácia, bordadeira do município de Cururupu, detalha a técnica por ela utilizada para alcançar a perfeita simetria no bordado do couro: "O couro do boi agente tem que cortar, cortar, alinhavar, costurar, aí vai dividir. Tem que dividir o quarto com a pá do boi. É cortado aí divide para botar o desenho certinho bem no meio. E vai bordando". Há grupos que preferem os couros bordados no veludo já fixado na carcaça, o que confere maior beleza ao bordado, visto que o couro fica totalmente esticado. (IPHAN, 2011, p. 147-185)
\end{abstract}

Tomei a liberdade de uma citação longa, porque ela sintetiza o processo de formação do couro de maneira mais apropriada do que eu faria, posto que (como disse anteriormente), nas minhas observações e entrevistas não me detive neste tipo de informação. Seguindo essa trilha, percorrida pelo Dossiê do Iphan, uma informação é muito preciosa no que se refere ao bordado, que se casa com a definição de coisa proposta por Ingold (2012): não há uma técnica préestabelecida para a realização do bordado com os materiais acima mencionados. Como salienta o autor, o manusear das coisas, bem como sua variação devido a mudanças no ambiente - vento, chuva, calor, frio - implica em resistências e ao mesmo tempo porosidades (ou vazamentos) entre elas. Estas propostas conceituais estão relacionadas com a compreensão da percepção e dos sentidos, de modo a entender como o pensamento humano se liga ao mundo, indo além das operações abstratas da mente. Aqui me faz pensar em Bakhtin (1987) e sua definição de corpo cósmico e com orifícios que está aberto ao mundo. Certamente que ao bordar um tecido a porosidade tem que ser levada em conta muito seriamente. A textura do tecido, das linhas, o tamanho e espessura da agulha, bem como o próprio tamanho da linha e da agulha implicam em resultados diferentes, acrescendo-se miçangas, canutilhos, lantejoulas e paetês. Assim, as coisas de fato se fazem em fluxos e interconexões de materiais, dentre eles, nós humanos.

Minha mãe foi uma excelente bordadeira, dona Djanira. Fazia bordados delicados em ponto de cruz, o avesso parecia uma marca d'água. Ela seguia manuais, desenhos de revistas entretanto nunca o fazia sem usar a criatividade, pois tinha que se pensar no matiz das cores para que elas pudessem dar ao desenho escolhido maior beleza e revelar sua arte -, mas também 
improvisava, mesclando desenhos variados para compor novas paisagens, novos arranjos florais, novos movimentos. Lembro que ela criou uma belíssima toalha, para uma igreja no interior da Paraíba, na localidade rural chamada Montevidéu, totalmente composta por desenhos encontrados em diferentes revistas. Isso implicou medir o pano cuidadosamente, separar em partes simétricas de forma a compor uma narrativa das imagens de santos e divindades em consonância com o padroeiro da igreja, além disso, uma barra para dar enquadramento e ressaltar as figuras principais.

Recordo essa história pessoal porque ela exemplifica o processo de bordar o couro, de forma criativa ainda que tenha um desenho prévio a ser seguido. Nenhum plano é perfeito. É na ação, na atividade, no desenvolver das habilidades que interagimos com as coisas. Também porque nessa história a duração para realizar o bordado ganha concretude. Eu acompanhei todo o processo e, por meio dessa toalha religiosa, a habilidade dela, dona Djanira, compunha um tecido inerte, meadas de linhas paradas, agulhas de frio metal, em coisas que se transmutavam e, assim, também ela mudava-se e vazava da toalha, para a casa, para os gatos - que lhe faziam companhia - para o neto, para a cozinha - em busca de café - para um cigarro - que aviva a atenção. Não tenho certeza de quanto tempo durou o bordado, mas posso especular que pelo menos três meses se passaram entre a aquisição do material até a finalização. A toalha viajou, seguiu novas trilhas, e hoje está em outras mãos, sacralizada nos rituais católicos das missas, novenas e procissões. Tal qual o boi, que se iniciou com a coleta de vegetais na mata, passou pelo magarefe, continuou na compra do tecido e dos materiais variados do bordado, as figuras desenhadas em papel ou sobre o veludo, tomou forma pelas mãos de bordadeiras e de bordadores, foi fixado na carcaça, até ser finalizado para ser batizado e, finalmente, tornar-se livre para brincar em toda cidade. E assim, o miolo, ou a mióla Mauricéia, entra em cena.

\section{Eu não tenho paradeiro certo! Boi, miolo/mióla e brincantes}

...as coisas se movem e crescem porque elas estão vivas, não porque elas têm agência. (INGOLD, 2011, p. 34)

O título deste item, que repete parte do título deste artigo, é uma frase de Mauricéia, dita ao nos descrever como foi a trajetória dela dentro do grupo de bumba-meu-boi, criado por sua mãe para dançar no terreiro de Mina (religião de matriz africana), que ela conduzia em São Luís. Ao ganhar a rua, o boi foi denominado Bumba-meu-boi Unidos de São Bento. Nele, Mauricéia desempenhou diferentes personagens (detalharei mais adiante) até se tornar mióla, percorrendo o boi de forma itinerante que me parece fazer um par muito instigante com a citação de Ingold (2012, p. 38):

"A vida está sempre em aberto: seu impulso não é alcançar um fim, mas continuar seguindo em frente". Sendo assim, "o crucial é que comecemos pelo caráter fluido do processo vital, onde os limites são sustentados graças ao fluxo de materiais através deles". (INGOLD, 2012, p. 41). 
Sem ter a pretensão de fazer paralelos entre a vida vivida por Mauricéia e uma afirmação teórica de um antropólogo, considero essa confluência como inspiradora para iniciar a descrição de como o boi e o miolo se entrelaçam no processo de criar coisas que tem vida; que na verdade passam da definição de objetos com agência, para serem coisas que têm vida. É significativo que a pessoa, que se mete dentro do boi, seja denominada miolo: uma palavra que tem também o sentido de centro, do que está dentro, do que dá estofo ao que é vazio. Curiosamente, miolo também são os cérebros dos animais - especialmente bovinos - quando servidos como alimento. Segundo o Dossiê de Registro do Bumba-meu-boi, o miolo pode ser denominado de "tripa", "alma", "fato", "espírito", "condutor" ou "mulher do boi". (IPHAN, 2011, p. 148). Encerrando aqui o rol de metáforas para pensar esta denominação, passemos ao encontro entre o boi e o miolo.

Pelo já descrito, o boi é uma figura viva antes mesmo que o miolo o encontre. Ele se formou ao longo de fluxos que tentei descrever. Ele foi inclusive batizado, ganhando um nome, porém não recebeu os santos óleos, por não ser considerado uma criatura. O batismo, como ritual de passagem, inclui o nascituro no mundo dos vivos e garante sua posição no mundo dos mortos - morrer pagão é ter sua alma destinada ao limbo. Depois do batismo, este ser agora nomeado, protegido e abençoado, pode ganhar o mundo, para: apresentar-se, dançar, interagir, entreter, abençoar, pagar promessas a São João e a São Pedro, reverenciar seus pares, compadres, colegas, amigos, amigas e tantos propósitos mais...

O sentido que as coisas têm vida não é apenas movimento, mesmo paradas e inertes as coisas sofrem ações externas que as perpassam ${ }^{18}$. Uma pedra, exemplo de Ingold (2012), está viva na medida em que vai se erodindo pela água, pelo vento, pelo calor, pelo frio; e não exclui o movimento, pois ela pode rolar numa avalanche. Assim, também podemos pensar no boi feito para São João, ainda que ele não viesse a ser posto para dançar na festa, ele se manteria vivo na confluência dos encontros das linhas, rastros e trilhas feitas pelos humanos, pelos vegetais (fungos) e animais (traças), que iriam mudando-lhe a cor, o brilho, a textura do veludo, a vivacidade das estampas da barra/saia. É nesse sentido que as coisas são em devir e não como projetos antecipadamente pensados para guiar sua consumação.

Concordo com esta definição, pois os humanos passam a habitar o mundo de uma maneira menos soberana, como um transformador intencionado racionalmente para submeter o mundo e o ambiente. Nesse sentido, a história humana passa-se no mundo, entre coisas e ambiente históricos, cada um à sua maneira. Mas ela por si só parece-me incompleta, por não contemplar as intenções humanas que antecipam a ação - estando consciente que as consequências quase sempre são incontroláveis (ORTNER, 2011) ${ }^{19}$. E por isso tornam-se incompletas, porque nossas

18 Isso não significa que as coisas não tenham uma superfície limitante, mas antes que as superfícies têm, ganham e criam, porosidades a partir das quais elas vazam entre si. Por isso a preferência de Ingold pelo termo material e não materialidade, porque essa última conota agência e o autor prefere o termo vida para compreender o processo das relações entre as coisas (Cf. INGOLD, 2012).

19 Para mais detalhes ver Sherry Ortner (2011) e seus outros trabalhos sobre teoria da prática, cujo foco maior são as relações de poder a partir da prática dos agentes. 
intenções são praticadas - quando as são - a partir de posições ocupadas na vida social, que tem seus mecanismos de controle do que podemos ou não fazer.

Já mencionei anteriormente a questão acima. Aproveito aqui para trazer uma crítica de Marilyn Strathern (2014) sobre a noção de rede de Bruno Latour (2013), que tomo a liberdade de estender para Ingold (2012). A questão levantada por Strathern relaciona-se com o tamanho da rede e onde ela se interrompe. O que corta uma rede ${ }^{20}$ ? Para Strathern (2014), o corte é feito pelo estabelecimento da propriedade - seja intelectual ou seja sobre um bem material. Cito: "Assim, onde a tecnologia pode aumentar as redes, o estabelecimento de uma condição de proprietário garante que elas sejam cortadas do tamanho certo" (STRATHERN, 2014, p. 319).

As assimetrias de gênero dentro do bumba-meu-boi são muito vigorosas, resultando em exclusão das mulheres da encenação de personagens e de posições dentro da brincadeira (ALBERNAZ, 2010; 2011). Considero que este tipo de interdito, ainda que não se configure em propriedade no sentido estrito do termo, estabelece cortes que interrompem o fluxo das coisas e, dessa forma, o fluxo da vida de pessoas e coisas é descontinuado, ou direcionado para ações, espaços e relações que lhes são desfavoráveis. Passo a palavra a Mauricéia, que descreve suas diferentes personagens dentro do boi até tornar-se uma mióla.

Eu conheci o bumba boi através da minha mãe. Ela tem um terreiro de Mina, então esse boi foi formado (...). Aí foi um boizinho de côfo ${ }^{21}$ que ela mandou fazer em São Bento, e mandou trazer pra cá, pra São Luís.

Eu comecei por índia ${ }^{22}$. Com seis anos eu era índia do boi da minha mãe. Aí foi crescendo, crescendo, crescendo, fiz catorze anos a quinze, eu disse que não queria mais sair.

[depois saí] De índio. É a única mulher que saía de índio, quando viam era eu. Corpo pintado, porque eu tinha o corpo todo definido, isso aqui mesmo parecia o corpo de homem (...) Os meus seios não pareciam que eu era mulher (...) Só quando tirava o capacete, que eu soltava o cabelo, fazia "assim" [meneando a cabeça], e tirava o bustiê que fazia o peito ficar bem batidinho como homem, então pra mim foi uma coisa maravilhosa. Eu não tenho paradeiro certo!

...Eu quero experimentar um pouquinho de cada... aí depois dancei dois anos de Cazumbá. Aí depois desses dois anos foi que minha mãe ficou sem miolo, no boi. (...) Aí ela disse "gente, como é que a gente vai fazer se sair sem ter o boi rolando?! A gente tem que rolar com o boi, o boi tem que sair" eu digo "rapaz, eu vou tentar fazer o que eu to querendo". Fui ao barracão, peguei o boi, me benzi, fiz a minha oração (...), coloquei o boi na cabeça, fiquei rodando lá dentro do barracão pra eu não fazer feio na rua, que tinha muita gente indo para o ensaio. Então eu peguei o boi e saí. E ela queria saber quem é que tava debaixo do boi. Não tirei o boi nenhuma hora, enquanto o boi não parou. Quando eu fui tirar, ela "nossa, procurei você tava dormindo", mas eu tava debaixo do boi, daí, minha paixão agora é ser mióla. Que botaram o apelido agora mióla. (Entrevista com Mauricéia, São Luís, São João de 2009).

$20 \mathrm{Na}$ teoria de Latour (2013), a rede parece se comportar aberta e aglutinadora de mais elementos - humanos e não humanos.

21 Boizinho de côfo denomina um boi feito a partir de um cesto trançado, chamado genericamente de côfo. Portanto, não é um boi do tipo descrito neste artigo, mas um artefato menos elaborado.

22 Índia, índio e cazumbá são diferentes personagens do bumba-meu-boi maranhense referidos por Mauricéia durante a entrevista. 
Como se pode ler, a história de Mauricéia no boi é balizada por mudanças constantes. Ela passou por diferentes posições dentro do boi até assumir a condição de dar movimento a ele, de ser o seu miolo. De ser a pessoa que vai levá-lo ao movimento, dando à vida, que ele já tinha, intenções e agência ${ }^{23}$, para desempenhar de maneira adequada a dança do boi no centro da festa. Nas palavras dela "rapaz, eu vou tentar fazer o que eu to querendo". A partir daí, prepara-se em segredo para o manuseio do boi, para sentir-se segura em vir a público, tornar-se conhecida a medida em que leva o boi a ser conhecido e atuar adequadamente na sua função. Na sua fala não aparece dificuldade ou repetições de gestos que possam transformar-se em habilidade. Ela apenas foi lá e fez. Neste ponto, valho-me da citação de Ingold, com a qual concordo, para compreender como se deu o seu desempenho como mióla, aparentemente sem ter habilidade para tanto:

...reproduzir envolve um procedimento de interação, seguir envolve itineração. O (ou a) artista - assim como o artesão - é um itinerante, e seu trabalho comunga com a trajetória de sua vida. Além disso, a criatividade do seu trabalho está no movimento para frente, que traz à tona as coisas. Ler as coisas "para frente" implica (...) na improvisação (INGOLD, 2012, p. 38, grifos no original).

A trajetória de Mauricéia, percorrendo diferentes personagens dentro do grupo do boi, leva-a ao itinerário do próprio boi porque será sua condutora como mióla, constituindo juntos, a partir daí, os percursos que o Bumba meu boi Unidos de São Bento deve cumprir ao longo do ciclo da festa. A vida que ela nos conta coincide com o itinerário do boi e com seus valores: não ter paradeiro certo, ser inquieta e, por sua vez, criativa, de maneira a levar para frente o curso do vivido.

Bem assim é a dança feita pelo boi nos festejos, ele inspira-se na vida do animal nos pastos e nas vaquejadas - quase sempre representando bravura. Os passos precisos do miolo simulam docilidade ou agressividade nos movimentos do boi, alternadamente. O miolo maneja o boi para arremeter ou recuar; para fazer volteios, que aparentam fugas ou aproximar-se, seduzindo ou assustando os brincantes; para baixar a cabeça, menear ou subir com os chifres, fingindo marrar as pessoas; para sacudir os quartos, exibindo seu couro; para fazer ondulações com o corpo, girar, parecendo que vai alçar vôo. Com essa dança do miolo escondido embaixo do boi, ele torna-se a atração principal e, na maior parte da apresentação, permanece no centro do folguedo, em torno do amo, ameaçado pelo pai Francisco e protegido pelos vaqueiros vigilantes dos seus passos, que conduzem e se deixam conduzir no bailado conjunto. 


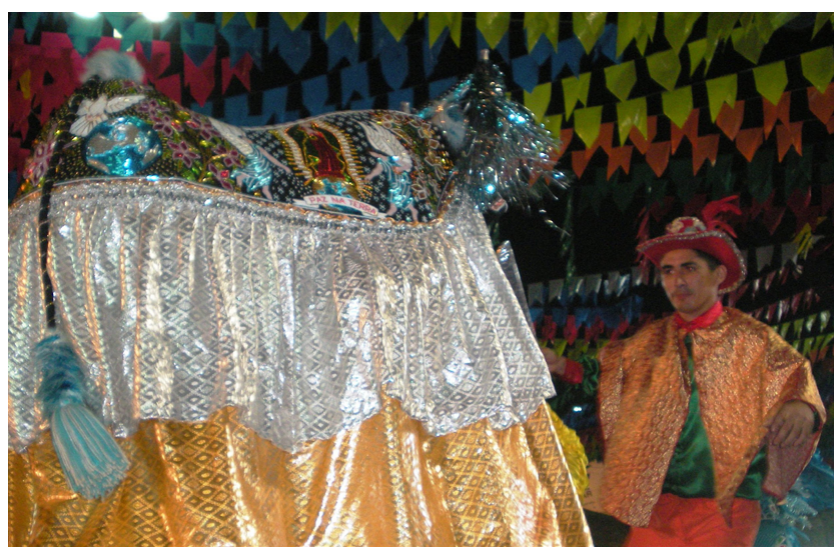

Imagem 4 - O boi dançando (Acervo da pesquisa - 2009)

Curiosamente, nos trabalhos variados que li sobre o bumba-meu-boi, o miolo é sempre citado, mas não teve sua fala registrada. Parece que a dimensão social das relações entre os brincantes - que embasam muitos desses trabalhos - não inclui quem são estes homens que portam o boi e lhe dão movimento ${ }^{24}$. Há o registro de que alguns deles ocupam esta posição para pagar promessa, os demais não têm suas motivações identificadas, mas são reconhecidos publicamente no Cortejo de Miolos “Iniciativa que reúne miolos de grupos de Bumba-meu-boi na primeira sexta-feira do mês de julho. Em cortejo pelas ruas do Centro de São Luís, os miolos apresentam suas performances sob a carcaça do Boi." (IPHAN, 2011, p. 77, nota 58). A citação, ao que me parece, reafirma que o miolo mantém-se em segredo, mesmo que o cortejo seja em sua homenagem. O que me leva a pensar que a vida do miolo não pode ser transposta para o boi, pois o boi é quem está vivo, e não animado pelo miolo, o qual quase nunca se dá a conhecer.

Agora cabe a pitada de gênero que expressei no início do trabalho. Em 2009, eu estava em campo com a estudante Patrícia Geórgia Barreto de Lima - bolsista de iniciação cientifica. A pesquisa enfocava as relações entre homens e mulheres no bumba-meu-boi, e as desigualdades que elas comportam ${ }^{25}$. Informaram-nos que a única posição que as mulheres não ocupavam era de miolo, mas descobrimos que havia uma. Assim fomos assistir ao Cortejo de Miolos, posto que aquela única mulher não tinha uma paradeiro identificado, não se sabia em que grupo ela brincava. Quando o cortejo encerrou partimos em busca da mulher miolo, disseram-nos que se chamava Mauricéia e tivemos que seguir seus rastros, pois ela já havia se despedido dos seus colegas de função. Seguimos na direção que nos indicaram e por sorte a encontramos. A entrevista foi feita ali mesmo na rua, recostadas numa mureta, pois nossa partida do campo já estava próxima. Três mulheres reunidas falando sobre o que significa estar em uma posição

24 No Dossiê do Registro do Bumba-meu-boi é citado o trabalho de Tácito Borralho, intitulado Miolo. Entretanto não tive acesso ao mesmo e sua citação no dossiê é uma descrição dos diferentes movimentos do boi, feitos pelos miolos, de acordo com os sotaques. (Cf. IPHAN, 2011, p. 181).

25 Destaco os seguintes trabalhos sobre gênero no bumba-meu-boi maranhense resultantes desta investigação: Albernaz (2010, 2011); Lima (2010) e Lima, Oliveira e Albernaz (2012). 
valorada simbolicamente como masculina e socialmente composta apenas por homens, sendo Mauricéia a exceção.

Aqui as relações sociais importam, pondo em evidência que as posições ocupadas para desempenhar essas relações podem permitir ou impedir o devir da vida e das coisas. Foi pelo impedimento das mulheres em ser miolo que Mauricéia deu-se a conhecer, a ela e, por conseguinte, aos miolos em geral, para mim. Hoje, em retrospecto, pergunto-me: por que não procurei outros miolos? Certamente não foi apenas por uma questão de tempo, mas antes porque eles não me atraiam a atenção, ficando ofuscados pela dança viva do boi no cenário da festa. O miolo apagava-se no não visto, emprestando momentaneamente sua vida ao boi, que a absorve com intensidade. As coisas de fato têm vida e seguem seus itinerários, mas o mundo social - chame-se sociedade ou socialidade - interfere no curso do seguir em frente que a vida nos pede. Talvez seja por isso que na sua teoria Ingold (2012) enfatiza a força mais do que a forma para tratar do mundo material, no sentido de que é a força que promove o fluxo. Assim, não surpreende que seja tão frequente, nos debates sobre gênero e cultura popular, afirmar que as mulheres não têm "força" suficiente para certas atividades, como justificativa para sua interdição.

Mauricéia está bem ciente disso. Reconhece o preconceito sofrido e naquela altura se regozijava com o carinho e a aceitação dos outros miolos, que lhe tinham como mascote do conjunto, depois de sete anos rolando o boi.

...preconceito? Tive demais, com o que eu faço, e hoje eu sou orgulhosa porque eu faço! (...) quando eu saía, nos arraiais que algumas pessoas pediam para tirar foto com o boi, só com o boi, eu saia "hum, mulher... coisa esquisita..." Chama na frente, "ai, que maravilhoso, uma mulher dançando.... Quando os garotos [refere-se aos miolos] me olharam, a primeira vez que eu cheguei para o Cortejo, eu fui a primeira a chegar, deles todinhos. Ninguém sabia. Botei o boi lá por dentro... fiquei lá, brincando... gente, quem vai ser o boi, do boi de Maria de Bala, Unidos de São Bento. Aí estou só calada... "Rapaz, como esse boi veio sozinho? Não acredito, eu sei que boi não tem pé..." Aí fiquei, quando disse assim, "vamos chamar Mauricéia que é hora de rolar o boi" "ah... ah, se ela rolar, eu não vou rolar!” [refere-se a fala de um miolo] Aí ficou aquele tititi. "Mas num pode, rapaz, é só homem, uma mulher não pode!" Eu fiquei caladinha, comecei a chorar... minha mãe falou: "você vai chorar? Levante a cabeça, que você enfrentou Deus e o mundo em arraial, você vai abaixar a cabeça aqui?” (Entrevista com Mauricéia, São Luís, São João de 2009).

Nesta passagem fica muito evidente que Mauricéia reconhece a hegemonia masculina na sociedade maranhense, o que se torna mais nítido porque ela ocupa a posição até então proibida para as mulheres. Sherry Ortner (1996) discute esta questão, mas ao mesmo tempo pensa no plano da prática dos agentes. Mesmo que a ideologia prevalecente afirme a superioridade do masculino, podem ocorrer práticas de resistência no plano individual ou até coletivo. Nesse sentido, a fala de Mauricéia explana práticas deste tipo: "Precisa de força, garra, muita paciência. Porque pra você ser um miolo, você tem que ter isso tudo. Rolo [rolar o boi] não é pra qualquer 
pessoa... Como eu acabei de falar, são dez quilo. E uma mulher, se não for como a eu é difícil" (entrevista com Mauricéia, São Luís, São João de 2009).

O itinerário de Mauricéia no boi foi de desafio, sendo índio, sendo cazumbá (mais frequentemente encarnado por homens) e, finalmente miolo, sendo reconhecida pelo substantivo "Mióla", o que projeta seu reconhecimento e aceitação. Entretanto, o que ela faz deve-se ao que ela percorreu no curso de sua vida, inclusive no plano pessoal, sobre o qual não me deterei aqui, o que me leva a retomar a discussão de Ingold sobre coisas, que surgem da junção de materiais e força. Neste caso, a força dela, Mauricéia, tanto para carregar e animar o boi, como para romper com as barreiras sociais de ser mulher - nosso cosmo particular - que nos interditam tantas coisas: "Trata-se do modo como materiais de todos os tipos, com propriedades variadas e variáveis, são avivados pelas forças do cosmo, misturadas e fundidas umas às outras na geração de coisas". (Ingold, 2012, p. 26).

Para não encerrar com desencanto, esperemos que o curso da vida possa tornar os miolos mais visíveis, sua força de animar as coisas, sua habilidade na dança, rolando o boi pelos arraiais. E, para as mulheres, que o curso da vida e as forças do cosmos transformem o mundo social que nos mantém - em variados aspectos - impedidas de seguir o fluxo dos materiais e, assim, possamos reencontrar autonomia no devir da vida.

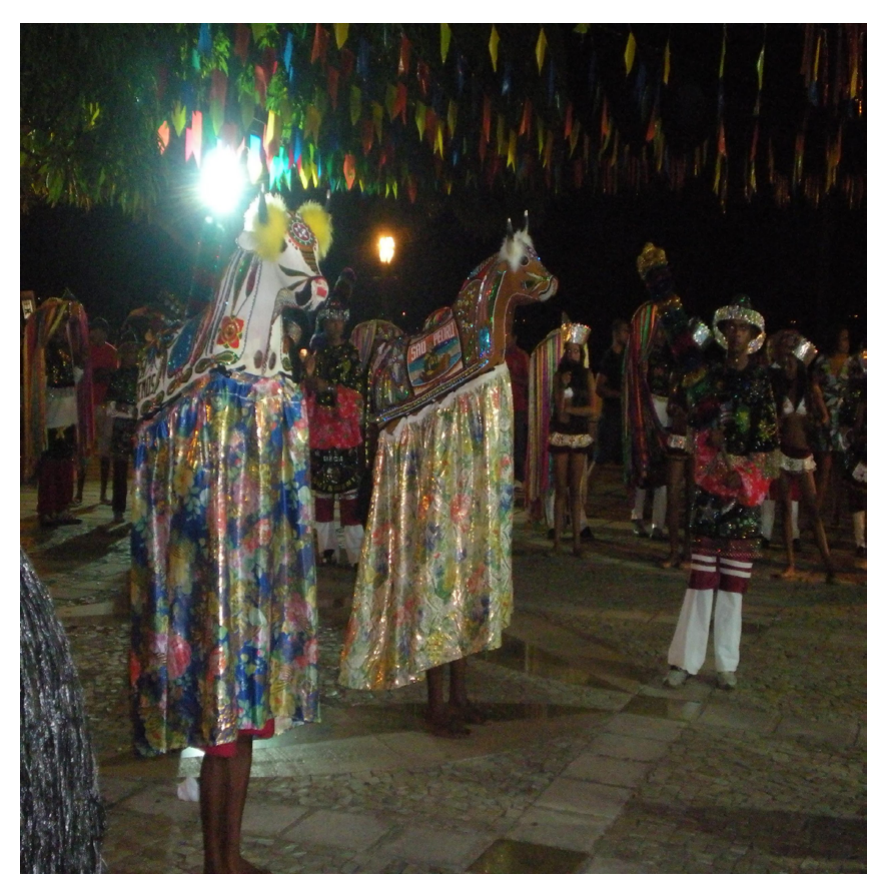

Imagem 5 - Boi e miolo (Acervo da pesquisa - 2009) 


\section{Despedida $^{26}$}

Neste artigo, me propus a analisar a relação entre humanos e não humanos, usando como exemplo etnográfico a junção entre boi e miolo. Revisitei dados que anteriormente havia interpretado apenas simbolicamente, com foco nas relações sociais e nas experiências que delas derivam. Refazer o percurso da descrição a partir do fluxo das coisas, no meu modo de ver, permitiu evidenciar os sentidos e a percepção humana no processo de produção simbólica, revelando novas possibilidades interpretativas dos mesmos dados. Por exemplo, a confecção do bumba-meu-boi inclui um conjunto de atividades, desempenhadas por pessoas com determinadas habilidades, as quais estão em relação por meio dele - o boi artefato - que se torna concreto pelos sentidos e percepções humanas e não apenas pela negociação simbólica do que nele será bordado. A eficácia do artefato é simultaneamente material e simbólica.

Foi por meio da junção boi e miolo que notei como a pessoa que compõe este personagem está ausente nas nossas interpretações. A figura do boi torna-se suficiente por sua densidade simbólica, o miolo aparece como sua extensão e não como pessoa-chave para o desenrolar da apresentação. Sem miolo o boi não dança. Nesse sentido, descrever os processos a partir dos quais as coisas e os humanos estão em fluxo pode fazer aparecer os seres humanos, suprimidos no ritual em favor da significação. Da mesma forma, quem assiste, ouve, dança e canta, envolve os demais sentidos - olfato, tato, paladar - durante o ritual. Neste engajamento de corpo e mente, sem hiatos, é que a compreensão do vivido toma novas formas e podem seguir novas direções para as pessoas. Talvez seja um modo de nos sentirmos mais humanos num tipo de sociedade que sobrepõe o mental ao sensorial quando define que tipo de espécie nós somos. Alargar a experiência para incluir o impensável e oxalá diminuir a miséria da teoria (aproveitando-me da ironia de Thompson (1998), citado antes).

Nos estudos de cultura popular, a sobreposição entre símbolos e matéria é constante e intensa. Conforme Bakhtin (1987), a estética do grotesco define o corpo como aberto e em contato com o cosmo. Considero, assim, que neste campo, o ganho analítico com o uso de uma teoria que põe em relevo o mundo material, em busca de uma teoria monista, pode ser muito vigoroso, contribuindo para alargar a compreensão e a interpretação de suas festas e rituais que engajam todos os sentidos. Por fim, parece-me que por esta entrada - observar como humanos e coisas vivem num fluxo de materiais - as relações de gênero podem ganhar nova substância, bem como novas possibilidades de transformação das desigualdades que teimam em lhes dar sentido moral.

\footnotetext{
26 Como são chamadas as toadas de encerramento das apresentações dos bois. Estas considerações finais me ocorreram após a leitura de um parecer sobre este artigo, que me fez notar que eu não tinha escrito um fechamento para o trabalho. Agradeço ao colega que me alertou, propiciando-me esta reflexão.
} 


\section{Referências}

ALBERNAZ, L. S. F.. Dinâmicas do bumba meu boi maranhense: classificação em sotaques e participação do público. Olhares Sociais, v. 02, p. 3-24, 2013.

Gender and musical performance in Maracatus (PE) and Bumba Bois (MA). Vibrant, Florianópolis, v. 8, p. 322-353, 2011.

Mulheres e cultura popular: gênero e classe no bumba meu boi do Maranhão. Maguaré, Universidad Nacional de Colombia, v. 24, p. 69-98, 2010.

O "urrou" do boi em Atenas: instituições, experiências culturais e identidade no Maranhão. Campinas: Universidade Estadual de Campinas, 2004. 346 f. Tese (Doutorado em Ciências Sociais) - Instituto de Filosofia e Ciências Humanas, Universidade Estadual de Campinas, Campinas, 2004.

BAKHTIN, M. A cultura popular na Idade Média e Renascimento: o contexto de François Rabelais. São Paulo/ Brasília: HUCITEC/UNB, 1987.

CARVAlHO, L. G. A Graça de Contar - Um pai Francisco no bumba meu boi do Maranhão. Rio de Janeiro: Aeroplano Editora, 2011.

Cd Bumba boi da Maioba: A nossa cultura. 2002.

INGOLD, T. Trazendo as coisas de volta à vida: emaranhados criativos num mundo de materiais. Horizontes Antropológicos, Porto Alegre, v. 18, n. 37, p. 25-44, June 2012 . Disponível em: <http://www.scielo.br/scielo. php?script=sci_arttext\&pid=S0104-71832012000100002\&lng=en\&nrm=iso >. Acesso em: 08 jun. 2018. http:// dx.doi.org/10.1590/S0104-71832012000100002.

Instituto do Patrimônio Histórico e Artístico Nacional. Complexo Cultural do Bumba-meu-boi do Maranhão. Dossiê do registro como Patrimônio Cultural do Brasil. Instituto do Patrimônio Histórico e Artístico Nacional. São Luís: Iphan/MA, 2011.

LATOUR, B. Reagregando o social: uma introdução à teoria Ator-Rede. Bauru: EDUSC, 2013.

LIMA, P. G. B. de. Índias, vaqueiras, mutucas, amas, miolos: relações de poder, posições e significados das mulheres nos grupos de bumba-boi do Maranhão. Recife: Universidade Federal de Pernambuco, 2010. 55f. Monografia (Graduação em Bacharelado em Ciências Sociais) - Centro de Filosofia e Ciências Humanas, Universidade Federal de Pernambuco, Recife, 2010.

LIMA, V. Homem-animal: a construção de uma metáfora na cultura popular brasileira. Textos escolhidos de cultura e arte populares, Rio de Janeiro, v.7, n.1, p. 121-145, mai. 2010.

OLIVEIRA, J. M.; LIMA, P. G. B. ALBERNAZ, L. S. F. Maracatus e bumba-bois: onde estão as mulheres? Revista Intratextos, Rio de Janeiro, v. 4, p. 181-200, 2012.

ORTNER, S. B. Teoria na Antropologia desde os Anos 60. Mana. Estudos de Antropologia Social, Rio de Janeiro, v. 17, n. 2, p. 419-466, 2011. Disponível em: www.scielo.br/pdf/mana/v17n2/a07v17n2.pdf Acesso em: 10 jun. 2018.

Making Gender: The Politics and Erotics of Culture. Boston: Beacon Press, 1996.

Poder e projetos: reflexões sobre a agência. In: GROSSI, M. P.; ECKERT, C.; FRY, P. H. (Orgs.). Conferências e diálogos: saberes e práticas antropológicas. REUNIÃO BRASILEIRA DE ANTROPOLOGIA, 25, Goiânia. Anais da 25 Reunião Brasileira de Antropologia. Blumenau: Nova Letra, 2007. p. 45-80.

PEIRANO, M. A análise antropológica de rituais. In: (Org.). O dito e o feito: ensaios de antropologia dos rituais. Rio de Janeiro: Relume Dumará, Núcleo de Antropologia Política/UFRJ, 2002. p. 17-40.

PRADO, R. P. S. Todo ano tem. As festas na estrutura social camponesa. Rio de Janeiro: Museu Nacional, 1977. 290 f. Dissertação (Mestrado em Antropologia). Museu Nacional, Rio de Janeiro, 1977. 
STRATHERN, M. Cortando a rede. In: O efeito etnográfico e outros ensaios. São Paulo: Cosac \& Naif, 2014. p. 295-319.

SUASSUNA, A. Romance d'A Pedra do Reino e o Príncipe do Sangue do Vai-e-Volta. 5a Ed. Rio de Janeiro: José Olynpio, 2004.

THOMPSON, E. P. Costumes em comum: estudos sobre a cultura popular tradicional. São Paulo: Companhia das Letras, 1998.

O termo ausente: experiência. In A miséria da teoria: ou um planetário de erros. Rio de Janeiro: Zahar Editores, 1981. p. 180-201.

Recebido em: 17/07/2018

Aceito em: 18/09/2018 